\title{
IMPLEMENTASI NILAI PANCASILA SEBAGAI SUMBER ETIKA, MORAL DAN KARAKTER DALAM PENERAPAN PELAYANAN KESEHATAN KEPERAWATAN
}

\author{
IMPLEMENTATION OF PANCASILA VALUES AS A SOURCE OF \\ ETHICS, MORALS AND CHARACTER IN THE IMPLEMENTATION OF \\ HEALTH SERVICES
}

\author{
Levi Olivia \\ Fakultas Kesehatan, Universitas Muhammadiyah Pringsewu \\ Email: leviolivia@umpri.ac.id
}

\begin{abstract}
Implementation Of Pancasila Values As A Source Of Ethics, Morals And Character In The Implementation Of Health Services. This study aims to determine the implementation of Pancasila values as the material basis for the formation of legislation in Article 6 of Law no. 12/2011. This research is a type of normative research with a prescriptive nature using a legal, historical, and conceptual approach. The types and sources of legal materials used are primary and secondary. Data collection techniques using literature research. Analysis of legal materials using a deductive syllogism. Based on the results of research and discussion, conclusions are drawn, the principle of content material has contained the values of Pancasila. The function of Pancasila education is to build the nation's character which must be maintained. Likewise, it is necessary to develop values, namely the ethical values of Pancasila, which are the nation's fundamentals in order to strengthen the integrity of health service providers, namely a nurse. As a real effort for the preservation of the noble values of Pancasila, it is necessary to instill understanding into the next generation of the nation, one of which is through Pancasila education in the next level of education. The Pancasila course is a learning process using a student centered learning approach, to develop students' knowledge, attitudes, and skills as future leaders of the nation in building their professional spirit in accordance with their respective study programs by making the values of Pancasila as the guiding principle. so that they become good citizens, especially in the application of nursing ethics.
\end{abstract}

Keywords: Pancasila ethics, morals, character, nursing services

Abstrak: Implementasi Nilai Pancasila Sebagai Sumber Etika, Moral Dan Karakter Dalam Penerapan Pelayanan Kesehatan. Penelitian ini bertujuan mengetahui implementasi nilai-nilai Pancasila sebagai asas materi muatan pembentukan peraturan perundang-undangan dalam Pasal 6 UU No. 12/2011. Penelitian ini merupakan jenis penelitian normatif bersifat preskriftif dengan menggunakan pendekatan undang-undang, historis, dan konseptual. Jenis dan sumber bahan hukum yang digunakan yaitu, primer dan sekunder. Teknik pengumpulan data menggunakan literature research. Analisa bahan hukum menggunakan silogisme deduksi. Berdasarkan hasil penelitian dan pembahasan dihasilkan kesimpulan, asas materi muatan telah memuat nilai-nilai Pancasila. Fungsi pendidikan Pancasila adalah membangun karakter bangsa yang harus tetap dipertahankan. Begitu pula perlu dikembangkan nilai-nilai yaitu nilai Etika Pancasila menjadi fundamental bangsa dalam rangka penguatan integritas para pemberi pelayanan kesehatan yaitu seorang perawat. Sebagai upaya nyata demi kelestarian nilai-nilai luhur Pancasila, perlu ditanamkan pemahaman kepada generasi penerus bangsa, salah satunya lewat pendidikan Pancasila dalam jenjang pendidikan seterusnya. Mata kuliah Pancasila merupakan proses pembelajaran dengan menggunakan 
pendekatan student centered learning, untuk mengembangkan knowledge, attitude, dan skill mahasiswa sebagai calon pemimpin bangsa dalam membangun jiwa profesionalitasnya sesuai dengan program studinya masing-masing dengan menjadikan nilai-nilai Pancasila sebagai kaidah penuntun (guiding principle) sehingga menjadi warga negara yang baik (good citizenship) terutama dalam penerapan etika keperawatan.

Kata Kunci : etika Pancasila, moral, karakter, pelayanan keperawatan

\section{PENDAHULUAN}

Pendidikan sebagai arena untuk mengaktifkan karakter luhur bangsa Indonesia, yang secara historis bangsa Indonesia memiliki karakter kepahlawanan, nasionalisme, semangat kerja keras serta berani menghadapi segala tantangan. Persoalan karakter terjadi di setiap lini kehidupan dimulai dari masa pendidikan awal. Realita dan fenomena yang ada pada saat sekarang ini adalah bangsa Indonesia mengalami penurunan nilai moral seperti konflik, pelecehan, budaya berbohong, kenakalan remaja, hingga korupsi. Dari hal tersebut yang menyebabkan terjadinya kemunduran dan hancurnya sebuah Negara.

Krisis moral yang melanda bangsa Indonesia diungkapkan oleh Winataputra dan Budimansyah (2007:166) adalah kekerasan , pelanggaran lalu lintas, kebohongan public, arogansi kekuasaan, korupsi kolektif, kolusi dengan baju profesionalisme, nepotisme local dan institusional, penyalahgunaan wewenang, konflik antar pemeluk agama, pemalsuan ijazah, konflik buruh dengan majikan, konflik antar partai, konflik antara rakyat dengan penguasa, demonstrasi yang cenderung merusak, otonomi daerah yang berdampak tumbuhnya etnosentrisme dan lain-lain.

Jika melihat dari hal-hal tersebut maka pantaslah bangsa Indonesia perlu mengatasi permasalahan tersebut, pemerintah harus membina dan membangun bangsa dengan menanamkan nilai-nilai positif melalui pendidikan karakter yang berbasis pada Pancasila sebagai sumber etika dan moral dalam berbagai bidang kehidupan terutama dikembangkan dan ditanamkan kepada anak anak bangsa sejak dini, agar bangsa ini memiliki generasi yang memiliki karakter yang positif dan mampu bersaing dengan Negara lain di era globalisasi.

Gagasan pembangunan bangsa unggul sebenarnya telah ada semenjak kemerdekaan Republik Indonesia diproklamasikan 17 Agustus 1945 oleh Presiden Sukarno, telah menyatkan perlunya nation and character building sebagai integral dari pembangunan bangsa. Beliau menyadari bahwa karakter suatu bangsa berperan besar dalam mempertahankan eksistensi bangsa Indonesia. Cukup banyak contoh empiris yang membuktikan bahwa karakter bangsa yang kuat berperan besar dalam mencapai tingkat keberhasilan dan kemajuan bangsa.

Melalui Pendidikan Pancasila sebagai sumber etika dan moral dapat membentuk karakter untuk membantu perkembangan jiwa generasi penerus bangsa. Sekolah memiliki kewajiban mengembangkan karakter melalui pendidikan Pancasila yang tertanam dan terimplementasi agar segala krisis moral yang menjadi tantangan bangsa dapat terkikis dengan menguatnya nilai-nilai Pancasila dan nilai nasionalisme kepada para peserta didik, demi terwujudnya gerasi penerus selau warga masyarakat bangsa dan Negara, agar berguna dan bermakna serta mampu mengantisipasi hari depan yang senantiasa berubah dan selalu terkait dengan konteks dinamika budaya, bangsa dan Negara dan hubungan internasionalya. Pendidikan tinggi tidak dapat mengabaikan realita kehidupan yang mengglobal yang digambarkan sebagai perubahan yang penuh denga paradoksal dan ketakterdugaan.

Penguatan Pancasila melalui Pendidikan Pancasila ini sesuai dengan Undang-Undang Nomor 20 tahun 2003 tentang Sistem Pendidikan Nasional pasal 1 yang berbunyi : "Pendidikan Nasional adalah pendidikan yang berdasarkan Pancasila dan Undang-Undang Dasar republic Indonesia 1945 yang berakar pada nilai-nilai agama, kebudayaan nasional Indonesia dan tanggap terhadap tuntutan zaman”. Sedangkan Pasal 3 berbunyi “Pendidikan nasional berfungsi untuk mengembangkan kemampuan dan membentuk watak serta peradaban bangsa yang bermartabat dalam rangka mencerdaskan kehidupan bangsa bertujuan untuk berkembangnya potensi peserta didik agar menjadi manusia yang beriman dan bertaqwa kepada Tuhan Yang Maha Esa, berakhlak mulia, sehat, 
berilmu, cakap, kreatif, mandiri dan menjadi warga Negara yang demokratis serta bertanggung jawab".

Menurut Notonegoro bangsa Indonesia berPancasila dalam tri-prakara yaitu : a. Pancasila Negara, b. Pancasila adat kebudayaan dan c. Pancasila religious. Kemampuan warga Negara agar memiliki hidup yang berguna dan bermakna serta mampu mengantisipasi perkembangan, perubahan masa depannya, sangat memerlukan pembekalan ilmu pengetahuan, teknologi dan seni (ipteks) yang berlandaskan nilai-nilai keagamaan dan nilai-nilai budaya bangsa. Nilai-nilai dasar Negara tersebut akan menjadi panduan dan mewarnai keyakinan serta pegangan hidup warga Negara dalam kehidupan bermasyarakat, berbangsa dan bernegara ( M. Syamsudin. 2011: 11).

Tulisan ini mencoba memberikan gambaran tentang bagaimana Pancasila di kuatkan dalam perkembangan karakter. Reilly dan Oberman dalam Yahya, (2002) mengatakan bahwa keperawatan merupakan suatu aktivitas intervensi untuk kesehatan individu saat berinteraksi dengan lingkungan mereka disemua tahapan kehidupan baik dalam keadaan sakit atau sehat. Etika keperawatan merupakan suatu aspek moral filosofi yang memberikan petunjuk tentang baik dan buruk dari tindakan. oleh karenanya tenaga perawat harus terbentuk karakter yang sesuai dengan harapan sila sila Pancasila. agar tindakan terkait praktik keperawatan tetap menjaga mutu dan kualitas profei keperawatan dalam menerapkan pola asuh keperawatan.. Eetika dan moral Pancasila yang sudah menjadi pedoman hidup bangsa Indonesia, agar generasi penerus bangsa ini dapat mewujudkan apa yang menjadi cita cita bangsa dengan menghadapi segala tantangan dimasa mendatang.

\section{METODE}

Metode pendekatan penelitian ini adalah menggunakan library research. Metode ini akan digunakan untuk menjawab studi pendahuluan (prelimentary research) untuk memahami lebih mendalam gejala yang tengah berkembang di lapangan atau dalam masyarakat (Zed, 2004). Selanjutnya menurut Zed (2004:54), menjelaskan bahwa riset kepustakaan adalah serangkaian kegiatan yang berkenaan dengan metode pengumpulan pengumpulan data pustaka, membaca dan mencatat serta mengolah bahan penelitian.

Proses penyusunan artikel ini dimulai dari pengumpulan data yang dilakukan dengan studiliterasi, yaitu mengidentifikasi berbagai referensi yang terkait dengan judul artikel. Data dan informasi tersebut, didapatkan dari berbagai literatur yang terkait dengan artikel dan anggapan yang didasarkan dari data-data sesuai dengan topic pembahasan. Berdasarkan anggapan tersebut, selanjutnya dilakukan tindak lanjut dengan mengelompokkan data secara sistematis untuk memberikan penjelasan dari anggapan tersebut. Setelah itu, data yang telah dikumpulkan secara sistematis dianalisis dan ditafsirkan untuk menjelaskan fenomena dengan alur ilmiah. Maka dengan demikian, akan menciptakan dan menghasilkan sebuah solusi terhadap persoalan yang ditulis dalam artikel ini.

Beberapa jenis literatur yang digunakan dalam melakukan riset ini adalah terdiri dari bukubuku dan artikel jurnal mengenai Pendidikan Pancasila dan Kewarganegaraan serta artikel mengenai etika keperawatan untuk menumbuhkan karakter sesuai dengan Etika keperawatan.

Teknik pengumpulan data menggunakan teknik dokumentasi, melakukan pencocokan data dari buku-buku, jurnal dan literatur terkait yang memiliki korelasi dengan artikel ini. Setelahnya akan diterjemahkan kembali menjaditranskrip , catatan dan sebagainya untuk memperoleh kevalidan data (Miles\&Huberman. 1992)

Analisis data dilakukan secara induktif, yang didalamnya terdiri dari dua tahap yaitu proses reduksi data dan peyajian data. Reduksi data bertujuan untuk penulis lebih mudah dalam memilih data yang valid, sedangkan penyajian data agar memungkinkan penarikan kesimpulan. Penarikan kesimpulan didapatkan sesudah merujuk tujuan penulisan, analisis dan sistesis. Simpulan juga memperhatikan penyajian data dari pembahasan yang ditarik merepresentasikan pokok-pokok bahasan dalam karya tulis serta didukung dengan saran praktis sebagai rekomendasi selanjutnya. 


\section{HASIL}

Istilah karakter/watak banyak dijumpai dalam ilmu psikologi. Soedarsono (2002: 67) mendefinisikan kepribadian sebagai totalitas kejiwaan seseorang yang menampilkan sisi yang didapat dari keturunan dan sisi yang didapat dari pendidikan, pengalaman hidup, serta lingkungannya. Karakter adalah sisi kepribadian yang didapat dari pengalaman, pedidikan dan lingkungan sehingga bisa dikatakan bahwa karakter adalah bagian dari kepribadian. Cloud (2007) mendefinisikan karakter sebagai kemampuan seseorang untuk memenuhi tuntutan kenyataan. sejalan dengan Cloud, Ezra (2006) mengatakan bahwa karakter adalah culture untuk sebuah kesuksesan yang langgeng dan tahan uji. Kemudian Chopra (2005) menyatakan bahwa karakter adalah sifat-sifat yang dimiliki oleh mereka yang telah mencapai tingkat kesadaran Tuhan sebenarnya sama persis dengan karakter/sifat-sifat yang dimiliki oleh sel tubuh manusia.

Lincona (1991:51) dalam bukunya Educating for Charakter menjelaskan tentang pengertian karakter dalam pembelajaran, yaitu sebagai berikut : "Charakter consist of operative value, values inaction. Charakter conceived has three in terrelated parts: moral knowing, moral feeling and moral behavior. Good character consist of knowing the good, desiring the good and doing the good-habits of the mind, habits of the heart and habits of action". pernyataan di atas dapat dijelaskan bahwa karakter terdiri atas nilai-nilai tindakan. Karakter dipahami mempunyai tiga komponen saling berhubungan yaitu pengetahuan moral, perasaan dan perilaku moral. Karakter yang baik adalah perilaku yang baik dari pemikiran, kebiasaan dan tindakan yang baik.

Sementara itu Koesoema A (2007:80) bahwa karakter sama dengan kepribadian.. kepribadian dianggap sebagai "cirri atau karakteristik atau gaya atau sifat khas dari diri seseorang yang bersumber dari bentukan-bentukan yang diterima dari lingkungan, misalnya keluarga pada masa kecil dan juga bawaan seseorang sejak lahir. Prof. Suyanto Ph.D menyatakan bahwa karakter adalah cara berpikir dan berperilaku yang menjadi cirri khas tiap individu untuk hidup dan bekerjasama baik dalam lingkup keluarga, masyarakat, bangsa dan Negara.

Sedangkan definisi karakter menurut Victoria Neufeld dan David B. Gunalnik (dalam Raka, 2007) adalah "distinctive trait, distinctive quality, moral strength, the pattern of behavior found in an individual or group”. Kamus Besar Bahasa Indonesia belum memasukkan kata-kata yang ada adalah 'watak' yang diartikan sebagai sifat batin manusia yang mempengaruhi segenap pikiran dan tingkah laku, budi pekerti, tabiat.

Dari berbagai pendapat diatas dapat disimpulkan bahwa karakter berkaitan dengan kekuatan moral, berkonotasi 'positif' bukan netral. Jadi orang yang berkarakter adalah orang yang mempunyai kualitas moral (tertentu) positif. Dengan demikian pendidikan adalah membangun karakter, yang secara implicit mengandung arti membangun sifat atau pola perilaku yang didasari atau berkaitan dengan dimensi moral yang positif atau baik, bukan negative atau yang buruk. Hal ini didukung oleh Peterson dan Seligman (Raka, 2007:5) yang mengaitkan secara langsung 'charakter strength' adalah kebajikan. Charakter strength dipandang sebagai unsur-unsur psikologis yang membangun kebajikan (virtues). Salah satu kriteria utama dari character strength adalah karakter tersebut berkontribusi besar dalam mewujudkan sepenuhnya potensi dan cita-cita seseorang dalam membangun kehidupan yang baik, yang bermanfaat bagi dirinya dan bagi orang lain.

Menurut Yusman, Kharis. Dkk (2013, hlm. 10) menyatakan bahwa etika keperawatan merupakan suatu aspek moral filosofi yang memberikan petunjuk tentang baik dan buruk dari tindakan. tindakan tersebut terkait dengan pratik keperawatan yang tetap menjaga mutu dan kualitas profesi keperawatan. orientasi utama sebuah profesi adalah menyalahgunakan keahlian yang dimiliki untuk kepentingan masyarakat. Akan tetapi tanpa disertai suatu kesadaran diri yang tinggi, profesi dapat dengan mudahnya disalahgunakan oleh seseorang, karena itu perlu pemahaman atas etika profesi dengan memahami kode etik profesi.

Tujuan pendidikan Etika Keperawatan untuk :

1. Meningkatkan pengertian tentang hubungan atar profsi kesehatan lain dan mengerti tentang peran serta fungsi anggota tim kesehatan

2. Mengembangkan profesi pengambilan keputusan tentang baik dan buruk yang akan dipertanggung jawabkan kepada Tuhan 


\section{Vol 10 No 2 Juli 2021 | Page 113-121}

3. Mengembangkan sifat pribadi dan sikap professional.

4. Mengembangkan pengetahuan dan ketrampilan yang penting untuk dasar praktik kperawatan professional

5. memberi kesempatan menerapkan ilmu dan prinsip etik keperawatan dan dalam situasi nyata (Yusman. Dkk. 2013 hlm. 11).

\section{Tujuan dan Hakekat Pendidikan Karakter bagi profesi Keperawatan}

Tujuan pendidikan karakter menurut Prof. Dr. H. E. Mulyana ( 2013:9) adalah untuk meningkatkan mutu proses dan hasil pendidikan yang mengarah pada pembentukan karakter dan akhlak mulia peserta didik secara utuh, terpadu, dan seimbang, sesuai dengan standar kompetensi lulusan pada setiap satuan pendidikan. Melalui pendidikan karakter peserta didik diharapkan mampu secara mandiri meningkatkan dan menggunakan pengetahuannya, mengkaji dan menginternalisasikan serta mempersonalisasikan nilai-nilai karakter dan akhlak mulia sehingga terwujud dalam perilaku sehari-hari. Pendidikan karakter pada tingkat satuan pendidikan mengarah pada pembentukan budaya sekolah yaitu nilai-nilai yang melandasi perilaku, tradisi, kebiasaan sehari-hari, serta symbol-simbol yang dipraktikkan oleh semua warga sekolah, dan masyarakat sekitarnya. Budaya sekolah merupakan cirri khas, karakter atau watak, dan citra sekolah tersebut dimata masyarakat luas.

Sedangkan menurut Sjarkawi (2006:39) mengungkapkan bahwa pendidikan karakter bertujuan membina terbentuknya perilaku siswa yang baik bagi setiap orang. Artinya, pendidikan nilai karakter bukan sekedar memahami tentang aturan tetapi juga mengenai penerapan nilai budaya yang membentuk akhlak seseorang.

Objek etika manurut Franz Magnis-Suseno13 adalah pernyataan moral. Apabila diperiksa segala macam moral, pada dasarnya hanya ada dua macam, yaitu, pernyataan tentang tindakan manusia dan pernyataan tentang manusia sendiri atau tentang unsur-unsur kepribadian manusia seperti motif-motif, dan watak. Ada himpunan pernyataan ketiga yang tidak bersifat moral, tetapi penting dalam rangka pernyataan tentang tindakan. Berdasarkan pendapat Franz Magnis-Suseno tersebut membuat skema sebagai berikut:

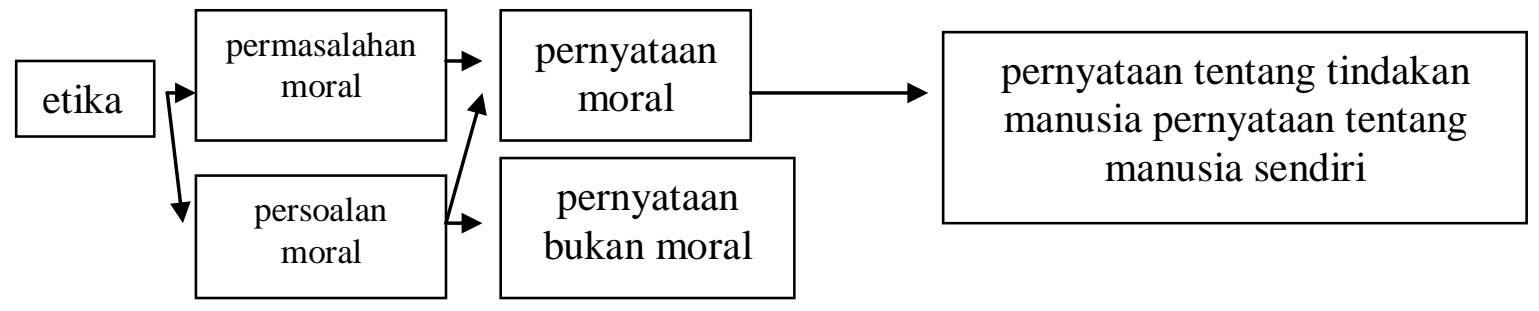

Nilai Pancasila yang digali dari bumi Indonesia sendiri merupakan pandangan hidup/panutan hidup bangsa Indonesia. Kemudian, ditingkatkan kembali menjadi Dasar Negara yang secara yuridis formal ditetapkan pada tanggal 18 Agustus 1945, yaitu sehari setelah Indonesia merdeka. Secara spesifik, nilai Pancasila telah tercermin dalam norma seperti norma agama, kesusilaan, kesopanan, kebiasaan, serta norma hukum. Dengan demikian, nilai Pancasila secara individu hendaknya dimaknai sebagai cermin perilaku hidup sehari-hari yang terwujud dalam cara bersikap dan dalam cara bertindak. Misalnya, gotong-royong.

Notonagoro juga berpendapat bahwa nilai-nilai Pancasila tergolong nilai-nilai kerohanian, tetapi nilai-nilai kerohanian yang mengakui adanya nilai material dan nilai vital. Dengan demikian, nilainilai lain secara lengkap dan harmonis, baik nilai material, nilai vital, nilai kebenaran, nilai keindahan atau nilai estetis, nilai kebaikan atau nilai moral, maupun nilai kesucian yang sistematika- hirarkhis, yang dimulai dari sila Ketuhanan Yang Maha Esa sebagai 'dasar' sampai dengan sila keadilan sosial bagi seluruh rakyat Indonesia sebagai 'tujuan'.

Menurut Mulyasa, Prof dalam Manajemen Pendidikan Karakter, norma adalah tolok ukur/alat untuk mengukur benar salahnya suatu sikap dan tindakan manusia. Norma juga bisa diartikan sebagai aturan yang berisi rambu-rambu yang menggambarkan ukuran tertentu, yang di dalamnya terkandung nilai benar/salah. Dalam bahasa Inggris, norma diartikan sebagai standar. Di samping itu, norma juga 
bisa diartikan kaidah atau petunjuk hidup yang digunakan untuk mengatur perilaku manusia dalam kehidupan bermasyarakat maupun bernegara. Jika norma dipahami sebagai standar (ukuran) perilaku manusia, yang dapat dijadikan "alat" untuk menghakimi (justifikasi) suatu perilaku manusia (benar atau salah), maka dalam realitas kehidupan sehari-hari terdapat palng tidak 5 norma, yaitu (1) norma agama, (2) norma hukum, (3) norma moral atau susila, (4) norma kebiasaan, dan (5) norma kesopanan. Norma agama adalah tolok ukur benar salah yang mendasarkan diri pada ajaran-ajaran agama. Dalam agama-agama selalu ada perintah dan larangan. Ada halal haram lengkap dengan sanksi-sanksi bagi pelanggar ajaranajaran agama. Norma agama itu tentunya berlaku bagi pemeluknya karena beragama itu dasarnya adalah keyakinan.

Norma hukum adalah norma yang dituntut dengan tegas oleh masyarakat dan dianggap perlu demi kemaslahatan dan kesejahteraan umum.Norma moral atau susila adalah tolok ukur yang dipakai masyarakat untukmengukur kebaikan seseorang. Tolok ukur penilaiannya adalah ukuran baik dan buruk berdasarkan nilai-nilai yang dijunjung tinggi atau yang dianggap rendah masyarakat tempat manusia yang bersangkutan itu berada. Dengan norma moral itu, seseorang benar-benar dinilai perilakunya. Norma kebiasaan adalah tolok ukur perilaku manusia yang berdasarkan pada hal-hal yang telah berlangsung dalam masyarakat sebagai suatu adat istiadat atau kebiasaan sehari-hari.

Pelanggaran norma biasanya mendapatkan sanksi, tetapi tidak selalu berupa hukuman di pengadilan atau penjara. Sanksi dari norma agama lebih ditentukan oleh Tuhan. Oleh karena itu, hukumannya berupa siksaan di akhirat, atau di dunia atas kehendak Tuhan. Sanksi pelanggaran/ penyimpangan norma kesusilaan adalah moral yang biasanya berupa gunjingan dari lingkungannya.

Penyimpangan norma kesopanan dan norma kebiasaan, seperti sopan santun dan etika yang berlaku di lingkugannya, juga mendapat sanksi moral dari masyarakat, misalnya berupa gunjingan atau cemoohan. Begitu pula norma hukum, biasanya berupa aturan-aturan atau undang-undang yang berlaku di masyarakat dan disepakati bersama. Norma adalah aturan-aturan dan ketentuan-ketentuan yang mengikat warga masyarakat atau kelompok tertentu dan menjadi panduan, tatanan, padanan dan pengendali sikap dan tingkah laku manusia. Agar manusia mempunyai harga, moral mengandung integritas dan martabat pribadi manusia. Sedangkan derajat kepribadian sangat ditentukan oleh moralitas yang dimilikinya, maka makna moral yang terkandung dalam kepribadian seseorang tercermin dari sikap dan tingkah lakunya. Oleh karena itu, norma sebagai penuntun, panduan atau pengendali sikap dan tingkah laku manusia. Pada mulanya norma berarti alat tukang batu atau tukang kayu yang berupa segitiga. Dalam perkembangannya norma berarti ukuran, garis pengarah, atau aturan, dan kaidah bagi pertimbangan serta penilaian.

Nilai yang menjadi milik bersama didalam satu masyarakat dan telah tertanam dengan emosiyang mendalamakan menjadi norma yang disepakati bersama.Segala hal yang kita beri nilai baik, cantik atau berguna akan kita usahakan supaya diwujudkan kembali di dalam perbuatan kita. Sebagai hasil usaha itu maka timbul ukuran perbuatan atau norma tindakan. Norma yang diterima oleh anggota masyarakat selalu mengandung sanksi dan pahala.

1.Tidak dilakukan sesuai norma hukuman; celaan dan lain sebagainya.

2.Dilakukan sesuai dengan norma pujian; balas jasa dan sebagainya. Jadi skemanya sebagai berikut: (Dalami, dkk: 2010, hlm 38)

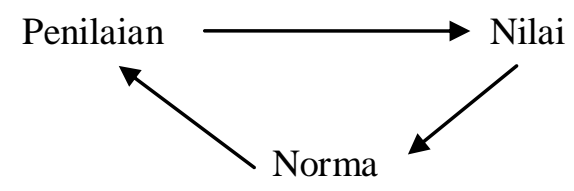

Ada banyak macam norma. Ada norma-norma khusus, yaitu norma yang hanya berlaku dalam bidang dan situasi yang khusus,. Agar nilai menjadi lebih berguna dalam menuntun sikap dan tingkah laku manusia terutama dikalangan remaja, maka ia perlu lebih dikonkretkan lagi serta diformulasikan menjadi lebih objektif sehingga memudahkan manusia untuk menjabarkannya dalam tingkah laku.Wujud yang lebih konkret dari nilai adalah norma. Terdapat berbagai macam norma.

Dari berbagai macam norma tersebut norma hukumlah yang paling kuat keberlakuannya, karena dapat dipaksakan oleh kekuatan eksternal seperti penguasa atau penegak hukum. Selanjutnya nilai dan 
norma senantiasa berkaitan dengan moral dan etika. Istilah moral mengandung integritas dan martabat pribadi manusia. Derajat kepribadian seseorang amat ditentukan oleh moralitas yang dimilikinya. Makna moral yang terkandung dalam kepribadian seseorang itu tercermin dari sikap dan tingkah lakunya. Dalam pengertian inilah maka kita memasuki wilayah norma sebagai penuntun sikap dan tingkah laku anak bangsa.

Menurut Aryaning A., Agus Riyanto dan Hendar Putranto untuk melaksanakan Pancasila perlu usaha yang dilakukan secara berencana dan terarah berdasarkan suatu pola. Tujuannya adalah agar Pancasila sungguh-sungguh dihayati dan diamalkan oleh segenap warga Negara, baik dalam kehidupan orang seorang maupun dalam kehidupan kemasyarakatan. Berdasarkan pola itu diharapkan lebih terarah usaha-usaha

a. Pembinaan manusia Indonesia agar menjadi insan Pancasila

b. Pembangunan bangsa untuk mewujudkan masyarakat Pancasila

Kedua hal tersebut di atas, tidaklah dapat dipisahkan satu sama lain, melainkan saling mempengaruhi dan saling mendukung. Masalah pembinaan insan Pancasila lebih banyak menyangkut bidang pendidikan. Lewat kegiatan pendidikan diharapkan peserta didik menyerap nila-nilai moral Pancasila. Penyerapan nilai-nilai moral Pancasila diarahkan berjalan secara manusiawi dan alamiah tidak saja lewat pengalaman secara pribadi. Nilai-nilai moral Pancasila tidak untuk sekadar dipahami melainkan untuk dihayati, oleh karena itu penyerapan nilai-nilai- moral Pancasila bukan lewat proses indoktrinasi. Nilai-nilai Pancasila pada hakikatnya bukanlah merupakan suatu pedoman yang langsung bersifat normative atau praktis melainkan merupakan suatu system nilai etika yang merupakan sumber norma baik meliputi norma moral maupun norma hukum, yang pada gilirannya harus dijabarkan lebih lanjut dalam norma-norma etika, moral maupun norma hukum dalam kehidupan sehari hari terutama dalam penerapan pola asuh keperawatan oleh tenaga perawat.

Penerapan Pacasila sila 1 (pertama) oleh tenaga perawat adalah mengenai Truth (kebenaran), dalam segala hal diawali dengan memohon kesembuhan untuk pasien, sila ke 2 (kedua), Aesthetich (keindahan), mempunyai rasa empati dan peduli kepada pasien, sila ke 3 (ketiga) Altruism (mengutamakan orang lain) memberikan arahan dan motivasi kepada pasien agar tetap semangat, sila 4 (keempat) Hukum Dignity (martabat manusia) membangun komunikasi terapeutik kepada pasien dan keluarganya, sila 5 (kelima) Justice ( keadilan) memperlakukan pasien dengan baik tanpa membedakan latar belakangnya dan Equality ( kesetaraan) setiap pasien berhak mendapat perlakuan yang sama .

Pendidikan Pancasila merupakan salah satu mata pelajaran pendukung pengembangan karakter manusia. Pendidikan Pancasila di sekolah dasar sangat penting artinya, karena merupakan proses awal pembentukan karakter bagi manusia di mana akan berlanjut samapai manusia itu menemui ajalnya.

Magnis-Suseno berpendapat bahwa Para peserta didik akan memiliki perilaku dan tingkah laku yang terpuji, jika di dalam dirinya tertanam nilai-nilai luhur dan ajaran-ajaran moral yang kesemuanya itu ada dalam Pancasila Peserta didik di perguruan Tinggi merupakan calon generasi penerus sekaligus alon pemimpin masa depan bangsa Indonesia. Oleh karena itu materi tentang Pancasila sudah menjadi sebuah kewajiban untuk diajarkan di Sekolah sebagai awal pembentukan karakter. Selain sebagai pembentukan karakter manusia juga merupakan upaya untuk melestarikan nilai-nilai Pancasila.

Kadang kala nilai-nilai luhur yang ada dalam Pancasila yang merupakan penjelmaan dari seluruh bangsa Indonesia tidak dipraktekan dalam kehidupan sehari-hari, tetaipi diabaikan sehingga akibat dari itu nilai-nila luhur tersebut dengan sendirinya akan hilang. Menyadari bahwa untuk kelestarian nilai-nilai Pancasila itu perlu diusahakan secara nyata dan terus-menerus pengahayatan dan pengamalan nila-nilai luhur yang terkandung di dalamnya, oleh sebab itu setiap warga Negara Indonesia, penyelenggara Negara, serta lembaga kenegaraan dan lembaga kemasyarakatan baik di pusat maupun di daerah harus sama-sama mengamalkan nilai-nilai Pancasila demi kelestarianya.

Oleh karena itu sebagai upaya nyata demi kelestarian nilai-nilai luhur Pancasila, perlu ditanamkan dan atau perlu ada pemahaman kepada generasi penerus bangsa, salah satunya lewat pendidikan pancasila di sekolah dasar maupun jenjang pendidikan seterusnya seperti termuat dalam pasal 5 Keputusan Direktur Jenderal Pendidikan Tinggi Departemen Pendidikan Naional Republik Indonesia Nomor: 43/DIKTI/Kep/2006 tentang rambu-rambu Pelaksanaan Kelompok Mata kuliah 
Pengembangan Kepribadian di Perguruan Tinggi, menegaskan bahwa dalam metodologi pembelajaran hendaknya:

1. Proses pembelajaran hendaknya diselenggarkan secara interaktif, menyenangkan, menantang, memotivasi peserta didik untuk berpartisipasi aktif, serta memberikan ruang yang cukup bagi prakarsa, kreativitas dan kemandirian, dengan menenpatkan mahasiswa sebagai subjek pendidikan, mitra dalam proses pembelajaran dan sebagai umat, anggota keluarga, masyaratat dan warga Negara.

2. Pebelajaran yang diselenggarakan merupakan proses yang mendidik, yang d dalamnya terjadi pembahasan krisis, analisis, induktif, deduktif, dan reflektif melalui dialog kreatif partisipatori untuk mencapai pemahaman tentang kebenaran substansi dasar kajian, berkarya nyata dan untuk menumbuhkan motivasi belajar sepanjang hayat.

3. Bentuk aktivitas proses pembelajaran, kuliah tatap muka, ceramah, dialog (diskusi) interaktif, studi kasus, penugasan mandiri, tugas baca, seminar kecil, dan kegiatan kurikuler.

4. Motivasi menumbuhkan kesadaran bahwa pembelajaran pengembangan kepribadian merupakan kebutuhan hidup untuk dapat eksis dalam masyarakat global.

\section{SIMPULAN}

Pendidikan Pancasila di setiap lini pendidikan memiliki peranan yang sangat penting, karena merupakan proses awal dari pembentukan karakter manusia Indonesia, dan akan berlanjut sampai manusia itu menemui ajalnya. Sekolah merupakan wadah yang pas untuk diajarkan pelajaran Pancasila sebagai langkah awal dalam rangka pembentukan karakter selanjutnya.

Di dalam Pancasila terkandung nilai-nilai luhur, ajaran-ajaran moral yang kesemuanya itu meruapakan penjelmaan dari seluruh jiwa manusia Indonesia.untuk menumbuhkan sikap professional dan melahirkan perawat professional diperlukan suatu system pendidikan yang bermutu berorientasi pada pengembangan ilmu pengetahuan dan kebutuhan masyarakat. Pendidikan Pancasila merupakan pedidikan nilai sehingga memiliki potensi untuk mengembangkan nilai-nilai etika keperawatan, agar tindakan perawat didasari pada karakter yang diharapkan sehingga kualitas pelayanan terhadap pasien menjadi lebih baikMenyadari bahwa untuk kelestarian nilai-nilai pancasila itu perlu diusahakan secara nyata dan terus-menerus pengahayatan dan pengamalan nila-nilai luhur yang terkandung di dalamnya,

\section{DAFTAR RUJUKAN}

Aryaning A., Agus Riyanto dan Hendar Putranto. Pendidikan Kewarganegaraan

(Civics). (Tangerang:UMN Press, 2012)

Cecep Triwibowo,2014. Etika dan Hukum Kesehatan, ( Yogyakarta: Nuha Medika)

Fudyartanto, Etika, (Yogyakarta: Warawidyani,1974), Cetakan Keempat.

Kansil C.S.T, Pancasila dan Undang-Undang Dasar 1945, Jakarta: PT Pradnya paramita

Moh. Nazir, Metode Penelitian, (Bogor Selatan: Ghalia Indonesia, 2005), h. 93

Magnis-Suseno, F. Etika Dasar :Masalah-masalah Pokok Filsafat Moral,(Yogyakarta: Kanisius, 1987)

Magnis-Suseno, F. Etika Politik: Prinsip-prinsip Moral Dasar Kenegaraan Modern, (Jakarta: PT Gramedia)

Mubarak, Zakky, Mata Kuliah Pengembangan Kepribadian Terintegrasi, Buku Ajar II, Manusia, Akhlak, Budi Pekerti dan Masyarakat. Depok, Lembaga Penerbit FE UI, 2008) 


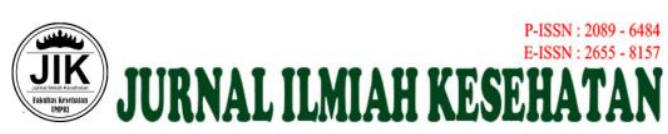

Vol 10 No 2 Juli 2021 | Page 113-121

Pangeran Alhaj S.T.S dan Surya Partia Usman, 1995. Materi Pokok Pendekatan Pancasila. Jakarta; Universitas Terbuka Depdikbud.

Setiady Elly M, Panduan Kuliah Pendidikan Pancasila, Jakarta: PT Gramedia Pustaka Utama.

Srijanto Djarot, Waspodo Eling,dkk. 1994. Tata Negara Sekolah Menengah Umum. Surakarta: PT. Pabelan.

Tanpa Nama.Tanpa Tahun. Pedoman Penghayatan dan Pengamalan Pancasila. Sekretariat Negara Republik Indonesia Tap MPR No. II/MPR/1987.

UU Nomor 32 Tahun 2003 tentang Sistem Pendidikan Nasional.

Keputusan Direktur Jenderal Pendidikan Tinggi Departemen Pendidikan Naional Republik Indonesia Nomor: 43/DIKTI/Kep/2006 tentang rambu-rambu Pelaksanaan Kelompok Mata kuliah Pengembangan Kepribadian di Perguruan Tinggi 